\title{
Bocchetti, Carla, El espejo de las Musas. El arte de la des- cripción en la Ilíada y Odisea, Santiago (Chile), Centro de Estudios Bizantinos y Neohelénicos, Facultad de Filosofía y Humanidades, 2006, 150 págs.
}

Cada nueva publicación sobre Ilíada y Odisea - a veintinueve siglos de su creación - testimonia la inagotable riqueza de la poesía homérica. Pero el mérito no es sólo de Homero. Muchas de estas aportaciones se fundan en la pericia de quienes han sabido leer e interpretar con agudo criterio y hurgar también allí donde otros no consideraron oportuno hacerlo. Entre ellos, sin duda debemos contar a la estudiosa colombiana Carla Bocchetti, que ofrece, en este su primer libro, una versión revisada de la que fue su tesis para la obtención de un Master of Arts por la Universidad de Warwick (Inglaterra). Prologada por Penelope Murray - uno de sus jurados - , la obra cuenta con una Introducción y ocho Capítulos en los que la autora sigue un derrotero que va desde la discusión de cuestiones más bien generales sobre la compleja relación de la literatura griega antigua con las artes visuales y la naturaleza, siempre en el marco de la composición formular típica de la épica, al análisis de representativos pasajes descriptivos de los poemas homéricos, con la atención puesta en la capacidad que dichos pasajes tienen para iluminar el contexto donde aparecen y en su estrecha relación con la trama de las piezas. Precisamente el propósito del libro consiste en superar aquella mirada crítica que ha reparado únicamente en el valor decorativo de la descripción. La

Palabras ClaVE: descripción, écfrasis, Homero, poesía épica, símil.

RECEPCIÓN: 19 de marzo de 2008.

ACEPTACIÓN: 22 de abril de 2008. 
écfrasis - como los antiguos llamaron a la descripción, entendida en su sentido más amplio como la descripción de lugares, paisajes, u objetos - resulta entonces el concepto vertebrador de este estudio, que no deja de lado otros tópicos relacionados, objeto de discusión de la estética más antigua (Platón, Aristóteles, Longino), como mimesis, phantasia y enargeia, entre otros.

El capítulo I ("Características de la poesía épica") llama la atención sobre el modus operandi del sistema de repetición formularia, que se vale comúnmente de imágenes vacías de un único y específico referente. Como bien afirma la autora, poco se ha estudiado la écfrasis en relación con el lenguaje formulario, pero es sólo a través de su contraste que puede ponderarse la innovación de la écfrasis homérica. La descripción en Homero, advierte Bocchetti, cumple con propósitos narrativos claves, aminorando el tempo narrativo en momentos previos a un suceso de importancia. El ejemplo que provee Ilíada, 22, 147-56, comentado en el capítulo II ("Memoria y repetición"), ilustra la posibilidad que brinda la écfrasis de dar cabida a temas y escenas de la vida cotidiana que de otro modo no tendrían lugar en un contexto guerrero. Se trata del episodio en que Héctor, cercado por Aquiles, se encuentra fuera de los muros de Troya, momento de suma tensión en que el narrador se permite describir los dos manantiales de agua caliente y fría que brotan del Escamandro y recordar a las hijas de los troyanos que, en tiempo de paz, lavaban en el lugar sus vestidos resplandecientes. En este, como en otros pasajes, la narración da muestras de cómo efectivamente puede liberarse del esquematismo de la repetición.

Es fácil ver que la écfrasis guarda una relación muy estrecha con los símiles, y la autora dedica un capítulo completo a evaluar el tipo de vinculación que los emparienta (Capítulo III: "Écfrasis y símiles"). Flora, fauna y fenómenos naturales constituyen los temas predilectos que el poeta épico tiene a su disposición para elaborar las comparaciones, con las cuales añade intensidad y pathos a la narración y "torna conocido lo desconocido" (p. 52), ya que reta al auditorio a identificarse con el mundo ordinario que estas recrean. Como las descripciones, los símiles crean una pausa en la narración, expandiendo el relato. Bocchetti retoma la división tradicional entre símiles breves y largos, estos últimos un rasgo peculiar de la épica homérica, ausente en otras epopeyas, y pasa revista a algu- 
nos símiles de la vida de caza, donde el león — de clara influencia oriental - cumple un papel protagónico. Se pone en evidencia que a partir de la comparación se crea una escena totalmente nueva, autocontenida, de vida propia. Concluye este tercer capítulo con el análisis de otro recurso narrativo equiparable en su eficacia al de los símiles, esto es, la intrahistoria. Aquella que explica la cicatriz de Odiseo ocasionada en la cacería en el Parnaso (Odisea, 19, 429-55), y la de la cacería del jabalí de Calidón, traída a cuento en relación con Meleagro (Ilíada, 9, 539), son objeto de un comentario más detenido.

Merece destacarse el capítulo dedicado a la descripción de los ríos y la naturaleza troyana en general (Cap. IV), en que Bocchetti demuestra su relevancia, sobre todo en Ilíada. Los ríos trascienden la mera referencia geográfica para valer como símbolos del país y de sus habitantes. Sabida por todos es la relación de Héctor con el Escamandro y la elevación de la geografía al estatus de personaje épico. Los símiles de los ríos que salen de su cauce, puntualiza la autora, refieren a un tiempo la desbordada ira de los héroes en la batalla y, otras veces, los presentan como aliados, tomando parte en la defensa del territorio. Se integran en la descripción de la naturaleza en general, representación que puede ser pacífica o destructiva. En opinión de Taplin ("The Shield of Achilles within the Illiad", 1980), a quien Bocchetti se adhiere, las descripciones de paisajes naturales idílicos - verdaderos paisajes sustitutos - hacen ver la guerra como inútil y destructiva. El otro grupo de descripciones, en cambio, propende a equiparar la muerte de los héroes con la destrucción de la naturaleza - recordemos que los héroes son comparados con las flores de su tierra. Observa la autora que sólo los héroes troyanos mueren "como los árboles", y es porque las muertes acaecen en su propio territorio. La destrucción del huerto de Eneo (Ilíada, 9, 532-44), que simboliza la muerte de los guerreros troyanos, y el secuestro de Licaón del huerto de su padre (Ilíada, 21, 34-44), índice revelador de la fertilidad de Troya, son los pasajes elegidos para ejemplificar estos temas.

Los siguientes dos capítulos, V y VI, enfocan el contexto agrario en Ilíada y Odisea respectivamente. Para ambos poemas vale la observación de que la patria ausente se construye en gran medida a partir de imágenes agrícolas de la tierra cultivada, que aluden cier- 
tamente a la idea de civilización. La delimitación territorial del témenos, entendido como la porción de tierra otorgada a un héroe por sus méritos, es una de las cuestiones abordadas en el libro, así como la relación de aquélla con la figura del padre: el liderazgo de un héroe se deja ver en la posesión de un territorio que perteneció también a sus ancestros. Un héroe se concibe en relación con sus posesiones, concentradas básicamente en su tierra natal, la que forma parte de su memoria. Odiseo ofrece un ejemplo paradigmático en tal sentido. El monte Nérito no es únicamente parte de la configuración del paisaje de Ítaca sino, y por sobre todo, una parte de la identidad de Odiseo. En ausencia del héroe, Ítaca se destaca como un terreno escarpado, un escenario rocoso que simboliza el peso de soportar el objetivo del regreso. Sin embargo, se convierte en una tierra fértil cuando el héroe está de vuelta: los cultivos de la isla se vuelven productivos, abundan los granos, las uvas crecen y se producen las lluvias. El huerto que reúne a padre e hijo al final del poema se explica en esa dirección. La autora considera que el reconocimiento de los árboles del huerto por parte de Odiseo constituye un aspecto de su identidad, al igual que su cicatriz o el ya aludido monte Nérito. Bocchetti aborda la cuestión desde una perspectiva teórica moderna, aplicando conceptos como los de la "geografía de la memoria" y la "imaginación cartográfica" que demuestran ser iluminadores en el análisis del texto homérico. No descuida, tampoco, aportes previos como los de Malkin (The Returns of Odysseus, 1998), Dougherty (The Raft of Odysseus: The Ethnographic Imagination of Homer's Odyssey, 2001) y Hartog (Mémoire d'Ulysse: récits sur la frontière en Grèce ancienne, 1996), a quienes comenta críticamente.

La descripción de objetos, especialmente joyas y telas, ocupan los dos últimos capítulos (VII: "Écfrasis homérica" y VIII: "La écfrasis general"). Bocchetti está convencida de la existencia de un imaginario compartido por poetas, artistas, orfebres y ceramistas, lo que vendría a explicar la analogía de la literatura con las artes representativas. Al artista le cabe el papel de seleccionar y combinar esta fuente común. El escudo de Aquiles, seguramente por el interés que acapara el detallismo de su descripción, ha concentrado regularmente la atención de los especialistas y, por regla general, ha sido juzgado como el ejemplo perfecto de la recreación literaria 
de una obra de arte que no puede encontrar correlato en la realidad. Recordemos su 'irreal' dinamismo. Sin embargo, no puede ser el suyo un ejemplo paradigmático al respecto, pues los anillos y sellos descriptos en la épica guardan similitud con los descubrimientos de la arqueología. Pero la preocupación a la autora está puesta en otro tipo de relación, en destacar los diferentes efectos narrativos que provoca una écfrasis. Así como las escenas de paz del mencionado escudo de Aquiles contrastan en medio de una guerra, la copa de Néstor está en franca relación con el estatus heroico de su dueño. La autora escoge el broche de Odiseo (Odisea, 19, 225-231) para brindar un estudio original sobre este objeto pequeño que, a decir verdad, ha pasado mayormente inadvertido, y que la tradicional traducción española de Luís Segallà confunde con una decoración de la túnica del héroe. El broche tiene grabado un perro atacando a un ciervo. La presencia de un perro, en lugar de la más recurrente figura del león, en opinión de la autora, anticipa el contexto doméstico del retorno del poeta. Estos objetos, señala Bocchetti, pueden tener relación con las ofrendas de culto funerario dedicadas a los héroes. Muchos de ellos, reflejo de un trasfondo de riqueza que rodea las acciones de los héroes, crean una atmósfera de brillo que la autora identifica con el brillo heroico, pero también con la provocación del terror y la capacidad de destrucción.

El volumen se cierra con una muy actualizada bibliografía sobre el tema que trata. Entre sus páginas, incluye una hermosa ilustración que reproduce la famosa imagen de Aquiles y Áyax jugando a los dados. El espejo de las Musas de Carla Bocchetti ofrece una mirada fresca sobre la descripción en Homero que ratifica la importancia del componente visual en la poesía épica. Con una prosa amena y didáctica, con las citas en griego totalmente traducidas, la lectura de este libro sin duda tendrá una muy buena acogida en todos los lectores de Homero - obviamente en los expertos, pero también en los profanos. 
